7. Reprod. Fert. (1967) 13, 563-566

BRIEF COMMUNICATION

\title{
LEUCOCYTIC RESPONSE TO SPERMATOZOA IN LIGATED SEGMENTS OF THE RABBIT VAGINA, UTERUS AND OVIDUCT
}

\author{
G. R. HOWE \\ Department of Physiology and Biophysics, University of Vermont College of Medicine, \\ Burlington, Vermont, U.S.A.
}

(Received 12th November 1966)

The fate of spermatozoa not participating in fertilization has been held to be enzymatic dissolution and phagocytic engulfment (Austin, 1957). Various investigators have observed sperm cells undergoing phagocytosis by polymorphonuclear leucocytes in the vagina and uterus (Yochem, 1929; Pitkjanen, 1960; Howe \& Black, 1963). There is some evidence which indicates that ovarian hormones influence the phagocytic removal of spermatozoa from the female genital tract (Bedford, 1965; Marcus, 1966). It was the purpose of this investigation to compare the leucocytic response of the rabbit vagina, uterus and oviduct to spermatozoa under different hormonal conditions.

In the present study, rabbit semen, collected by artificial vagina techniques, was diluted in a Krebs-Henseleit-Ringer (KHR) solution to a concentration of 300 million spermatozoa $/ \mathrm{ml}$. The diluted semen $(0.1 \mathrm{ml})$ was injected into ligated segments of the vagina (cervical half), of one uterine horn, and of one oviduct in a total of forty oestrous does. After incubation periods of 4 to 48 $\mathrm{hr}$, the segments were flushed and representative smears were air-dried and stained overnight in a dilute Delafield's haematoxylin $(1: 50)$. The leucocytic response was evaluated on a scale of low, medium or high in an attempt to compare the rate of leucocytic infiltration in different segments of the reproductive tract (Table 1). The rabbit semen induced a leucocytic response in the vagina, uterus and oviduct. Although there was considerable individual variation, there was a tendency for the initiation and attainment of a maximal leucocytic response in the oviducts to be slower than that in the vagina and uterus. Diluted semen incubated in duplicate by using both uterine horns and oviducts in the same doe resulted in equal degrees of leucocytic activity within each pair. There was active phagocytic engulfment of spermatozoa in all ligated segments 8 to $16 \mathrm{hr}$ after injection accompanied by a progressive decrease in the number of spermatozoa. Although there was a complete absence of spermatozoa in all smears obtained $24 \mathrm{hr}$ after injection, a high leucocytic response was still present in all 48-hr smears. The injection of sterile KHR solution into ligated segments of the vagina, uterus and oviduct was characterized by a negative leucocytic response. 
The injection of different concentrations of spermatozoa ( 7 to 190 million) into eighteen uterine segments in oestrous rabbits had no effect upon the incubation time required for the initiation of leucocytic infiltration or the attainment of a high response. After $3 \mathrm{hr}$ the smears were characterized by a low response ( 36 to 190 million spermatozoa injected), whereas a high response was seen after an 8-hr interval ( 14 or 178 million cells injected). There appeared to be, however, a relationship between the number of spermatozoa incubated and the time required for their complete removal from the segments.

Since bacteria are known to elicit a leucocytic response in the uterus (Broome, Winter, McNutt \& Casida, 1960; Heap, Robinson \& Lamming, 1962; Brinsfield, Hawk \& Righter, 1964), an experiment was performed to examine if there was a different response of the uterus and the oviduct to bacteria and spermatozoa. Semen ( 30 million spermatozoa, $0 \cdot 1 \mathrm{ml}$ ) was injected into one uterine and one oviduct segment, and non-sterile KHR solution $(0.1 \mathrm{ml})$

TABLE 1

LEUCOCYTIC RESPONSE AT OESTRUS IN LIGATED SEGMENTS OF THE VAGINA, UTERUS AND OVIDUCT TO RABBIT SPERMATOZOA*

\begin{tabular}{|c|c|c|c|c|c|c|c|c|c|}
\hline \multirow{3}{*}{$\begin{array}{l}\text { Time after } \\
\text { injection }(h r)\end{array}$} & \multicolumn{9}{|c|}{ No. of segments with leucocytic response $\dagger$} \\
\hline & \multicolumn{3}{|c|}{ Vagina } & \multicolumn{3}{|c|}{ Uterus } & \multicolumn{3}{|c|}{ Oviduct } \\
\hline & Low & Medium & High & Low & Medium & High & Low & Medium & High \\
\hline 4 & 3 & 0 & 0 & 7 & 1 & 0 & 1 & 0 & 0 \\
\hline 6 & 1 & 1 & 0 & 4 & 4 & 1 & 2 & 0 & 0 \\
\hline 8 & 0 & 2 & 3 & 0 & 1 & 6 & 1 & 3 & 1 \\
\hline 12 & 0 & 1 & 1 & 0 & 0 & 8 & 3 & 2 & 2 \\
\hline 16 & 0 & 0 & 2 & 0 & 0 & 3 & 0 & 1 & 1 \\
\hline 20 & 0 & 0 & 2 & 0 & 0 & 2 & 0 & 0 & 2 \\
\hline 24 & 0 & 0 & 2 & 0 & 0 & 4 & 0 & 0 & 2 \\
\hline 48 & 0 & 0 & 2 & 0 & 0 & 2 & 0 & 0 & 2 \\
\hline
\end{tabular}

* Incubation of 30 million spermatozoa.

$\dagger$ Leucocytic response $(400 \times$ magnification): Low, 1 to 10 polymorphs in each microscopic field; Medium, 11 to 100 polymorphs; High, too numerous to count.

was incubated on the opposite side (twelve oestrous does). There was no difference in the uterine response to semen or non-sterile KHR solution; however, in the oviduct there was little response to KHR solution until after $24 \mathrm{hr}$ compared to $16 \mathrm{hr}$ when semen was used. Large numbers of polymorphs were present in all segments flushed $48 \mathrm{hr}$ after injection. The injection of sterile KHR solution into segments resulted in no leucocytic infiltration (eight rabbits). The addition of penicillin (500 i.u. $/ \mathrm{ml})$ and streptomycin $(500 \mu \mathrm{g} / \mathrm{ml})$ to semen incubated in uterine and oviduct segments did not inhibit the infiltration of polymorphs or the phagocytosis of spermatozoa. Representative samples of the semen-antibiotic mixtures were cultured on agar plates, and bacterial growth was not observed on any plate.

In an attempt to show if there is a differential time response of leucocytic infiltration to spermatozoa and bacteria under different hormonal conditions, semen ( 30 million, $0.1 \mathrm{ml}$ ) or non-sterile $\mathrm{KHR}$ solution was incubated in uterine segments of oestrous does and in others pseudopregnant 11 days after 
ovulation, induced by 40 i.u. HCG injected intravenously. As shown in Table 2, leucocytes were mobilized more rapidly against spermatozoa in the oestrous uterus in that no appreciable polymorph infiltration was seen until $12 \mathrm{hr}$ after injection in luteal phase uteri. It was interesting to note that the incubation of non-sterile KHR solution in pseudopregnant animals resulted in a negative, leucocytic response up to $13 \mathrm{hr}$ after injection.

Observations by other workers (Merton, 1939; Howe \& Black, 1963; Reid, 1964) have revealed that spermatozoa undergo phagocytosis in the vagina and uterus following copulation or vaginal insemination; however, such activity was not characteristic of the oviducts, which suggested that possibly the oviducts were not capable of such defence mechanisms. The present study, however, has shown that ligated oviduct segments are capable of a leucocytic response comparable to the vagina and uterus in oestrous females. In contrast, the different portions of the genital tract in six oestrous does were

TABLE 2

LEUCOCYTIC RESPONSE OF THE UTERUS OF THE OESTROUS AND PSEUDOPREGNANT RABBIT TO SPERMATOZOA AND NON-STERILE KREBS SOLUTION

\begin{tabular}{c|cc|cc}
\hline \multirow{2}{*}{$\begin{array}{c}\text { Time after } \\
\text { injection }(\text { hr })\end{array}$} & \multicolumn{3}{|c}{ Leucocytic response in ligated uterine segment* } \\
\cline { 2 - 5 } & \multicolumn{2}{|c|}{ Oestrus } & \multicolumn{2}{c}{ Pseudopregnancy ${ }_{\ddagger}^{+}$} \\
\cline { 2 - 5 } & Spermatozoa† & Krebs & Spermatozoa & Krebs \\
\hline 6 & High & Low & Low & 0 \\
7 & High & Medium & - & - \\
8 & High & High & Low & 0 \\
9 & - & - & Low & 0 \\
10 & High & High & Low & 0 \\
12 & High & High & High & 0 \\
13 & High & High & High & 0 \\
\hline
\end{tabular}

* Leucocytic response $(400 \times$ magnification $)$ : Low, 1 to 10 polymorphs in each microscopic field; Medium, 11 to 100 polymorphs; High, too numerous to count.

$\dagger$ Incubation of 30 million spermatozoa.

$\ddagger 11$ days after ovulation.

flushed $12 \mathrm{hr}$ post coitum, and the smears revealed the presence of numerous polymorphs in both the vagina and uterus but none in the oviducts. This absence of leucocytic activity in the oviducts as compared to ligated oviducts might be explained, in part, by the fact that very few spermatozoa are found in the oviducts of mammals following copulation or vaginal insemination (Chang, 1956).

In that leucopenic females have shown a lack of defence mechanisms against bacteria as well as the inability to remove excess spermatozoa from the reproductive tract (Hawk, Turner \& Sykes, 1960; Menge, Tyler \& Casida, 1962), it would suggest that the infiltration of polymorphs plays a role in normal reproductive processes.

\section{REFERENCES}

Austin, C. R. (1957) Fate of spermatozoa in the uterus of the mouse and rat. F. Endocr. 14, 335.

BEDFORD, J. M. (1965) Effect of environment on phagocytosis of rabbit spermatozoa. F. Reprod. Fert. 9, 249. 
Brinsfield, T. H., HAwK, H. W. \& Righter, H. F. (1964) Interaction of progesterone and oestradiol on induced leucocytic emigration in the sheep uterus. F. Reprod. Fert. 8, 293.

Broome, A. W., Winter, A. J., McNutt, S. H. \& CAsida, L. E. (1960) Variations in uterine response to experimental infection due to hormonal state of the ovaries. II. The mobilization of leukocytes and their importance in uterine bactericidal acitivity. Am. F. vet. Res. 21, 675.

Chang, M. C. (1956) Reaction of the uterus on spermatozoa in the rabbit. Annali Ostet. Ginec. 78, 74.

HaWk, H. W., Turner, G. D. \& Sykes, J. F. (1960) The bactericidal properties of uteri and uterine exudates of rabbits with reduced leukocytic activity. Am. F. vet. Res. 21, 649.

Heap, R. B., Robinson, D. W. \& Lamming, G. E. (1962) The relationship between ovarian hormones and uterine infection in the rabbit. A possible mode of action. F. Endocr. 23, 351.

Howe, G. R. \& Black, D. L. (1963) Spermatozoan transport and leucocytic responses in the reproductive tract of calves. F. Reprod. Fert. 6, 305.

Marcus, S. L. (1966) Influence of ovarian hormones on the leukocytic response to spermatozoa in the uterus of the golden hamster. Fert. Steril. 17, 212.

Menge, A. G., Tyler, W. J. \& Casida, L. E. (1962) Factors affecting the removal of spermatozoa from the rabbit uterus. F. Reprod. Fert. 3, 396.

Merton, H. (1939) Studies on reproduction in the albino mouse. III. The duration of life of spermatozoa in the female reproductive tract. Proc. R. Soc. Edinb. 59, 207.

Pitkjanen, I. G. (1960) The fate of spermatozoa in the sow. Zh. obshch. Biol. 21, 28.

REID, B. L. (1964) Fate of residual sperm in the mouse uterus. 7. Anat. 98, 492.

Yochem, D. E. (1929) Spermatozoan life in the female reproductive tract of the guinea pig and rat. Biol. Bull. mar. biol. Lab., Woods Hole, 56, 274. 